\title{
ISOHEMOLYSINS IN HUMAN BLOOD, WITH ESPE- CIAL REFERENCE TO THE BLOOD OF THE NEW-BORN *
}

\author{
BASIL B. JONES, M.D. \\ BOSTON
}

The isohemolytic properties of human blood have been studied from time to time by various observers. Relatively few papers have appeared on this subject, however, in comparison to the large number on the closely related subject iso-agglutination. There is a marked difference in the results reported by different observers on the percentage of occurrence of isohemolysins in the blood of adults. The question of isohemolysins in the blood of new-born infants does not seem to have been investigated adequately. This study was begun to determine if isohemolysins had developed in the blood of new-born infants. It was subsequently extended to include a series of adults for the purpose of comparison under the same conditions of technic.

The first recorded observation on isohemolysis was made by Maragliano ${ }^{1}$ in 1892 . He stated that the serums of persons suffering from essential anemia, carcinoma, malaria, etc., have the property of destroying normal erythrocytes and changing hemoglobin to hemotoidin.

Following Maragliano's work, no noteworthy studies on isohemolysis were made until after Shattuck's ${ }^{2}$ and Landsteiner's ${ }^{3}$ observations on iso-agglutinins in 1900 . Their work stimulated many investigators to study iso-agglutination and also reawakened the interest of the scientific world for the hemolytic properties of human serum. Isohemolysins were at first considered as dependent on disease, but this theory was largely discarded after Landsteiner and Leiner ${ }^{4}$ in 1905 showed that approximately 50 per cent. of both normal and sick children had isohemolysins in their serum. They employed for their study the red cells of three persons, who from their description could fall into Groups II, III and IV of Moss' $^{5}$ classification. These cells were washed in

* Received for publication Aug. 25, 1921.

* From the Medical Services of the Massachusetts General Hospital

* This paper is No. 22 of a series of studies on the physiology and pathology of the blood from the Harvard Medical School and allied hospitals, a part of the expense of which has been defrayed from a grant from the Proctor Fund of the Harvard Medical School, for the study of chronic disease.

1. Maragliano: Verhandlungen des XI Kongr. f. Inn. Med., 1892.

2. Shattuck, S. G.: J. Path. \& Bacteriol. 6:303, 1900.

3. Landsteiner, K.: Zentralbl. f. Bakteriol. u. Parasitenk. 27:361, 1900.

4. Landsteiner, K. and Leiner, K.: Zentralbl. f. Bakteriol. u. Parasitenk. 38: $545,1905$.

5. Moss, W. L.: Johns Hopkins Hosp. Bu11. 21:63, 1910. 
physiologic sodium chlorid solution and a 2.5 per cent. suspension was made. It was observed that iso-hemolysis was not found as often as iso-agglutination and that a given serum might hemolyze either one or two of the three types of cells used. They stated that strong isohemolysis was seen only when agglutination had occurred.

It has become well recognized that human beings can be divided into four groups according to the way their serums agglutinate the corpuscles of others and by the agglutinability of their corpuscles with different serums. Moss' classification was followed in this study and is stated in Table 1:

TABLE 1.-Moss' Classification

\begin{tabular}{|c|c|c|c|c|}
\hline \multirow{2}{*}{ Cells } & \multicolumn{4}{|c|}{ Serum } \\
\hline & I & II & III & IV \\
\hline 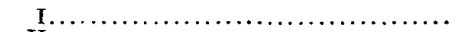 & - & + & + & + \\
\hline 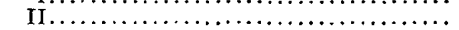 & - & - & + & + \\
\hline 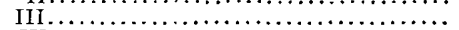 & - & + & 工 & + \\
\hline 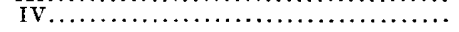 & - & - & 一 & - \\
\hline
\end{tabular}

$+=$ agglutination, $-=$ no agglutination.

In addition to his studies on iso-agglutination Moss also reported observations on isohemolysis. He used a technic quite similar to that employed by Landsteiner and Leiner, except that he used a 5 per cent. instead of a 2.5 per cent. suspension of corpuscles. He observed isohemolysins in 25 per cent. of 100 serums examined and stated that isohemolysis never occurred independently of iso-agglutination. Moss expressed the belief that iso-agglutinins and isohemolysins had a common origin. He showed that all serums contained an antihemolysin that protected the homologous corpuscles and those of the same group from dissolution by any other serum. Moss believed that antihemolysin was an anti-amboceptor which acted by uniting with the cytophylic group of the hemolysin, thus blocking it off from the red cell, and that the anti-hemolysin consisted of receptor groups from the red cells, which had been cast off from the cell or set free by the physiologic or pathologic destruction of the corpuscles.

Von Dungern and Hirschfeld, ${ }^{6}$ working at the same time as Moss (1910), studied the iso-agglutinins and their receptors in human blood. They confirmed the theory originally advanced by Landsteiner ${ }^{7}$ that only two iso-agglutinins, "a" and " $b$," and two receptors, "A" and "B," were present in human blood. They showed that the following combinations might occur in the blood of any one individual: $A$ and $B$, $A$ and $b, B$ and $a$, and $a$ and $b$, and suggested that these properties are inherited in accord with mendelian principles.

6. Von Dungern, E. and Hirschfeld, L.: Ztschr. f. Immunitätsforsch. u. Exper. Therap. 6:284, 1910 .

7. Landsteiner, K.: Wien, klin. Wchnschr. 46:1132, 1901. 
Grafe and Graham ${ }^{8}$ showed that the isohemolysins corresponded to the "a" and " $b$ " iso-agglutinins, and that disease had no etiologic relation to their presence in the serum.

Cherry and Langrock ${ }^{9}$ studied the blood of mothers and their newborn infants. They mixed equal amounts of infant's serum and a 5 per cent. suspension of washed corpuscles from the mother in one tube, and similar amounts of infant's cells and mother's serum in another. In thirty-four such tests they failed to observe either isoagglutination or isohemolysis. Their findings are not in accord with those of other observers.

Recently, Williams ${ }^{10}$ emphasized the fact that isohemolysis never occurs without associated iso-agglutination. He stated that when a serum has strong agglutinative power it may cause slight or no noticeable hemolysis in the quantity used. "The hemolysin is present, however, and can always be demonstrated when sufficient complement is present by increasing the amount of serum."

It is generally conceded that there are two isohemolysins among humans just as there are two isoagglutinins. Isohemolysins resemble the acquired hemolysins that originate after the injection of foreign blood into the body of an animal, in that they are thermostabile, specific, and that they require complement for their action. Complement is a nonspecific thermolabile substance found in all fresh serums. The process of isohemolysis consists of the attachment of the isohemolysincomplement complex to the corresponding receptor of a suitable red cell and the subsequent dissolution of the cell.

In this study the following technic was followed in studying the isohemolysins of both adult and infant blood: 0.2 c.c. of serum was added to 0.1 c.c. of a 5 per cent. suspension of known group cells which were twice washed and suspended in 0.9 per cent. sodium chlorid solution. Each serum was tested against cells of all four groups. The serums examined were assumed, because of their freshness, to have enough complement to insure hemolysis but in some instances this may not have been the case. (If this factor had been strictly controlled the results with adult serums might have more closely paralleled those of Williams.) The tubes containing the serum and cells were placed in a water bath at $37 \mathrm{C}$. for two hours and then were examined for the presence or absence of isohemolysis. Unless the cells had completely settled in this time the preparation was gently shaken and centrifuged slowly. This procedure permitted slight degrees of hemolysis to be detected which might otherwise have passed unnoticed, and in no instance did it seem to cause traumatic hemolysis.

8. Grafe, E. and Graham, D. A. L.: Münch. med. Wchnschr. 58:2257, 1911.

9. Cherry, T. H. and Langrock, E. G.: J. A. M. A. 66:626 (Feb. 26) 1916.

10. Williams, W. C.: J. Exper. M. 32:159, 1920. 
There were 265 specimens in all examined. Of this number 144 were from adults, and 121 were from new-born infants. Of the 140 samples.of adult blood belonging to Groups II, III and IV, 124, or 88.5 per cent. contained demonstrable isohemolysins. Of the twenty specimens ( 13.9 per cent.) which did not show isohemolysins, four belonged to Group I, which should have no isohemolysins, twelve to Group II, and two each to Groups III and IV. Of the 121 infant specimens, 117 belonged to Groups II, III and IV, and thirty-two of these showed isohemolysins, or 27.3 per cent. Table 2 shows the isohemolytic reactions of twelve adult and twelve infant serums which were chosen as representatives of the two kinds of blood.

TABLE 2.- Isohemolytic Reactions of Twelve Representative Adult Serums and Twelve Representative Infant Serums

\begin{tabular}{|c|c|c|c|c|c|c|c|c|c|}
\hline \multirow{3}{*}{ Group } & \multicolumn{4}{|c|}{ Adult Serum* } & \multirow[b]{2}{*}{ Group } & $:$ & \multicolumn{2}{|c|}{ Infant Serum* } & \multirow{3}{*}{ IV } \\
\hline & I & II & III & IV & & I & II & III & \\
\hline & $+\div$ & $+t$ & ++ & - & IV & + & +++ & - & \\
\hline III & $\operatorname{tr}$ & +7 & - & - & IV & tr & ++ & - & - \\
\hline IV & + & ++ & + & - & IV & $t r$ & tr & $\operatorname{tr}$ & - \\
\hline IV & + & $\operatorname{tr}$ & + & - & III & + & +++ & - & - \\
\hline III & tr & ++ & - & - & IV & - & tr & - & - \\
\hline IV & ++ & $+t$ & ++ & - & IV & tr & tr & $\operatorname{tr}$ & 一 \\
\hline II & + & - & + & - & IV & tr & - & $\mathrm{tr}$ & - \\
\hline II & tr & - & tr & - & IV & + & ++++ & tr & - \\
\hline II & +++ & - & +++ & - & II & ++ & - & ++ & - \\
\hline IV & ++ & + & ++ & - & IIII & - & + & - & - \\
\hline IV & +++ & +++ & +++ & - & IV & - & tr & - & - \\
\hline II & & & 1 & - & III & ?tr & $+t$ & - & -- \\
\hline
\end{tabular}

* The groups to which the serums belonged are indicated in the left hand column. The degrees of hemolysis of known group cells by the different serums are indicated in the other four columns.

An examination of this table brings out the chief differences between the isohemolytic reactions of adult and infant serums. It will be observed that adult serum, as a general rule, shows slightly stronger hemolytic power than infant serum. However, infant serum may contain isohemolysins which are quite as strong as those seen in adult serum. Adult serums of Group IV more frequently have both isohemolysins "a" and " $b$ " than do infant serums of this same group, but the same tendency for one isohemolysin to predominate is seen in both. Serums of Groups II and III, irrespective of the age of the person from whom they are obtained, show the same types of hemolytic reactions. The chief difference between adult and infant serums of these groups lies in the frequency of occurrence of isohemolysins. An analysis was made of the results obtained in the study of infant serums.

Four serums belonged to Group I, which never has isohemolysins, so, naturally, the tests were negative in all. Forty serums belonged to Group II. Of these forty specimens only two, or 5 per cent., showed the presence of isohemolysin. Isohemolysin "b," which occurs in this group, seems to be equally effective against cells of both Group 
I and Group III. (This fact was brought out more effectively from the study of adult serums.) Twenty serums belonged to Group III. Of these twenty serums there were seven, or 35 per cent., which contained isohemolysin. The isohemolysin "a," which occurs in this group, was much more effective against the Group II cells than against the Group I cells used. In three instances only Group II cells were hemolyzed, while in the other four instances the lytic action on Group II cells was much more marked than on Group I cells. This finding would suggest a preponderance of receptor " $\mathrm{B}$ " in the Group I cells used.

Fifty-seven serums belonged to Group IV. Of these fifty-seven specimens, twenty-three, or 40.3 per cent., showed isohemolysins. The results of a study of this group are shown in Table 3 .

TABLE 3.-Analysis of Isőhemolytic Reactions of Twenty-Three Infant Serums of Grotp IV Which Contained Isohemolysins

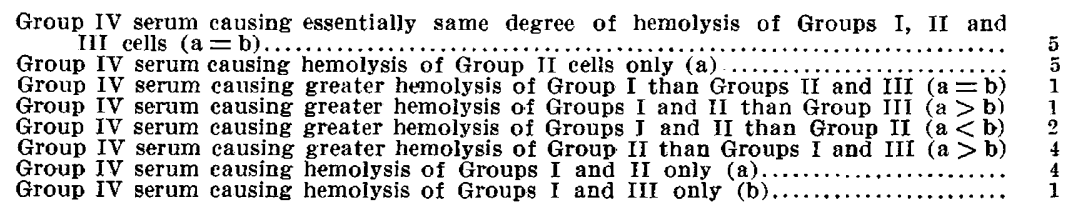

An examination of these results shows that both isohemolysins can be demonstrated in the blood of the new-born. The isohemolysin "a," which occurs in Groups III and IV, is much more often present at birth than isohemolysin "b," which occurs in serum of Groups II and IV.

Because of the striking predominance of isohemolysin "a" at birth, the results in the adult series were examined to see if this same tendency had persisted in adult life. It has been shown that sixteen of the 140 adult specimens belonging to Groups II, III and IV failed to show demonstrable isohemolysins. Twelve of the sixteen specimens belonged to Group II, and two each to Groups III and IV. These figures show that the same tendency for isohemolysin "a" to predominate exists in adult blood, but to a much less degree, than in infant blood. An analysis of the isohemolytic reactions of fifty-five adult serums of Group IV, shown in Table 4, also demonstrates this modified tendency for isohemolysin " $a$ " to predominate.

It has been suggested by Moss that iso-agglutinins and isohemolysins have a common origin. It is certainly true that these properties of serum are closely related and that isohemolysins never occur independently of iso-agglutinins. The development of isohemolysins, however, does not seem to keep pace with the development of iso-agglutinins, and the developmental difference between isohemolysins " $a$ " 
and " $b$ " is in sharp contrast with that of iso-agglutinins " $a$ " and "b." A study of iso-agglutinins in the serum of the new-born was reported in the previous paper. ${ }^{11}$ It was shown in this study that isoagglutinin " $a$ " occurred about as frequently as iso-agglutinin " $b$," which is in contrast to the development of isohemolysin " $a$ " over isohemolysin "b." Iso-agglutinins were demonstrated nearly three times as often as were isohemolysins in the same infant serum' while in adult serum isohemolysins were demonstrated nearly as frequently as iso-agglutinins.

TABLE 4.-Analysis of Isohemolytic Reactions of Fifty-Five Adult Serums of Group IV

Group IV adult serum hemolyzing equally Group II and III cells $(a=b) \ldots \ldots \ldots 25.4 \%$ Group IV adult serum hemolyzing Group II cells more markedly than Group III ( $\mathrm{a}>\mathrm{b}$ ) $41.8 \%$ Group IV adult serum hemolyzing Group III cells more markedly than Group IJ $(\mathbf{a}<\mathrm{b}) \quad 21.8 \%$ Group IV adult serum hemolyzing Group II cells only (a) $\ldots \ldots \ldots \ldots \ldots \ldots \ldots \ldots \ldots \ldots \ldots$

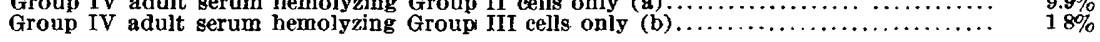

The effect on the degree of isohemolysis by increasing the number of cells in the individual tests was also investigated. This study was made because a comparison of the technics of the various observers suggested that varying the number of cells in the tests might exert an influence on the detection of weak isohemolysins. As indicated above, the results of different observers on the percentage occurrence of isohemolysins in human blood are quite different. A fixed amount of adult serum was tested against varying amounts of the cells of another group. The first observations strongly suggested that an increased number of cells did tend to prevent hemolysis. The cells in this series were washed twice in physiologic sodium chlorid solution, and two suspensions, one of 5 per cent. and one of 20 per cent., were made. Parallel tests were made using 0.2 c.c. of each cell suspension and 0.2 c.c. of serum. Table 5 shows the groups of the serums tested and the results of the various tests:

TABLE 5.-EFfect on DegreE of IsOHemolysis by INCREASING Number of Cells in Tests

\begin{tabular}{|c|c|c|c|c|c|c|c|c|c|c|c|c|c|}
\hline \multirow[b]{2}{*}{ Group } & \multicolumn{3}{|c|}{ 5\% Cells } & \multicolumn{3}{|c|}{$20 \%$ Cells } & \multirow[b]{2}{*}{ Group } & \multicolumn{3}{|c|}{$5 \%$ Cells } & \multicolumn{3}{|c|}{$20 \%$ Cells } \\
\hline & II & III & IV & II & III & IV & & II & III & I V & II & III & IV \\
\hline IV & + & - & - & tr & - & - & II & - & +++ & - & - & $\operatorname{tr}$ & - \\
\hline II & - & $+\div$ & 一 & - & $\operatorname{tr}$ & - & IV & $t r$ & $t r$ & - & - & - & - \\
\hline II & - & $\operatorname{tr}$ & - & - & - & - & IV & ++ & $\operatorname{tr}$ & - & $t r$ & $? \mathrm{tr}$ & $\rightarrow$ \\
\hline IV & $\operatorname{tr}$ & ++ & - & - & - & - & II & - & tr & - & - & - & - \\
\hline IV & $\operatorname{tr}$ & $? \operatorname{tr}$ & - & - & - & - & IV & $++t$ & ++ & - & $\operatorname{tr}$ & $? \mathrm{tr}$ & - \\
\hline IV & ++ & + & - & ?tr & ?tr & - & II & - & +++ & - & - & $\operatorname{tr}$ & - \\
\hline II & - & ?tr & - & - & - & - & IV & tr & ?tr & - & - & $\leftarrow$ & - \\
\hline I & - & -- & - & - & - & - & III & tr & - & - & - & - & - \\
\hline$I \bar{V}$ & - & $\operatorname{tr}$ & - & - & ?tr & - & II & - & +++ & - & - & + & - \\
\hline II & 一 & - & - & - & - & - & IV & + & +++ & - & - & + & - \\
\hline II & - & - & - & $\overline{0}$ & - & - & IV & ++ & + & - & tr & ?tr & - \\
\hline IV & + & ?tr & - & $? \dot{t r}$ & - & - & II & - & ++ & - & - & $\operatorname{tr}$ & - \\
\hline
\end{tabular}

Degrees of hemolysis are as indicated in Table 2.

11. Jones, B. B.: Am. J. Dis. Child. 22:586 (Dec.) 1921. 
The next series of observations were made to determine if the greater number of cells carried enough antihemolysin to decrease the amount of hemolysis observed in tests with fewer cells. The cells were washed three times instead of twice as in the previous experiment, and 2.5 per cent. and 25 per cent. suspensions were made instead of 5 and 20 per cent. Despite the greater differences in number of cells in the parallel tests, the differences in degree of hemolysis were not so marked as in the first series. A final series of tests were made with the same serums and cells as were used in the second series but this time the cells were washed five times instead of three. The tests still showed a very slightly greater amount of hemolysis when fewer cells were used, but the differences were less than in the tests with thrice washed cells. It would seem that these results could be explained on the basis of incomplete removal of antihemolysin, and the tests demonstrate that it is not an easy matter to remove all antihemolysin. It seems quite possible in the light of these results that the varying reports in the literature on the frequency of isohemolysis are in part dependent on varying amounts of antihemolysin present in the tests of various observers.

One practical application of this study lies in its relation to the question of transfusion of young infants. This matter was rather fully discussed in the paper on iso-agglutinins." It was suggested in this paper that tests for compatibility should be done before selecting donors for transfusion in infants. The results of this study show that about one third as many new-born infants have demonstrable isohemolysins in their blood as do adults, and further stress the desirability of doing compatibility tests before transfusing infants. The chief danger of transfusing infants from untested donors lies in the fact that isohemolysin " $a$ " is so frequently present at birth. Infants of Groups III and IV whose serums contain this hemolysin would presumably have hemolytic reactions if transfused from Group II donors.

\section{SUMMARY AND CONCLUSIONS}

1. One hundred and twenty-one specimens of blood from new-born infants and 144 specimens of adult blood have been examined for the presence of isohemolysins. Isohemolysins have been found in 27.3 per cent. of infant specimens of Groups II, III and IV, and in 88.5 per cent. of adult specimens of the same groups.

2. Besides the difference in frequency of occurrence of isohemolysins in adult and infant serums, the following differences were noted: (a) the isohemolysins of adult serums, as a general rule, appear to be slightly stronger than those seen in infant serums, but this is not universally true and some of the most intense reactions were observed 
in tests of infant serum. (b) Isohemolysin "a" which occurs in serums of Groups III and IV is much more frequently present at birth than isohemolysin " $b$ " which occurs in serums of Groups II and IV. This tendency for isohemolysin "a" to predominate is also seen in adult serums but to a much less degree than in infant serums.

3. When an excessive amount of red cells which have been twice washed in physiologic sodium chlorid solution is used for the isohemolytic tests, hemolysis will be inhibited. This inhibition of hemolysis seems to be due to the presence of antihemolysin in the cell suspension. Even after five washings in physiologic sodium chlorid solution some antihemolysin seems to be present in cell suspensions.

I wish to express my thanks to the members of the staff of the Boston Lying-In Hospital, whose assistance made possible the study of infant blood, and to Drs. George R. Minot, Roger I. Lee and William L. Moss for advice and criticism. 